ConF-9404123...

UCRL-JC-118866

PREPRINT

\title{
Carbonaceous Aerosols Influencing Atmospheric Radiation: Black and Organic Carbon
}

\author{
J.E. Penner \\ Lawrence Livermore National Laboratory \\ Livermore, California 94551
}

This paper was prepared for submittal to the

Dahlem Conference

Berlin, Germany

April 24-29, 1994

September 1994

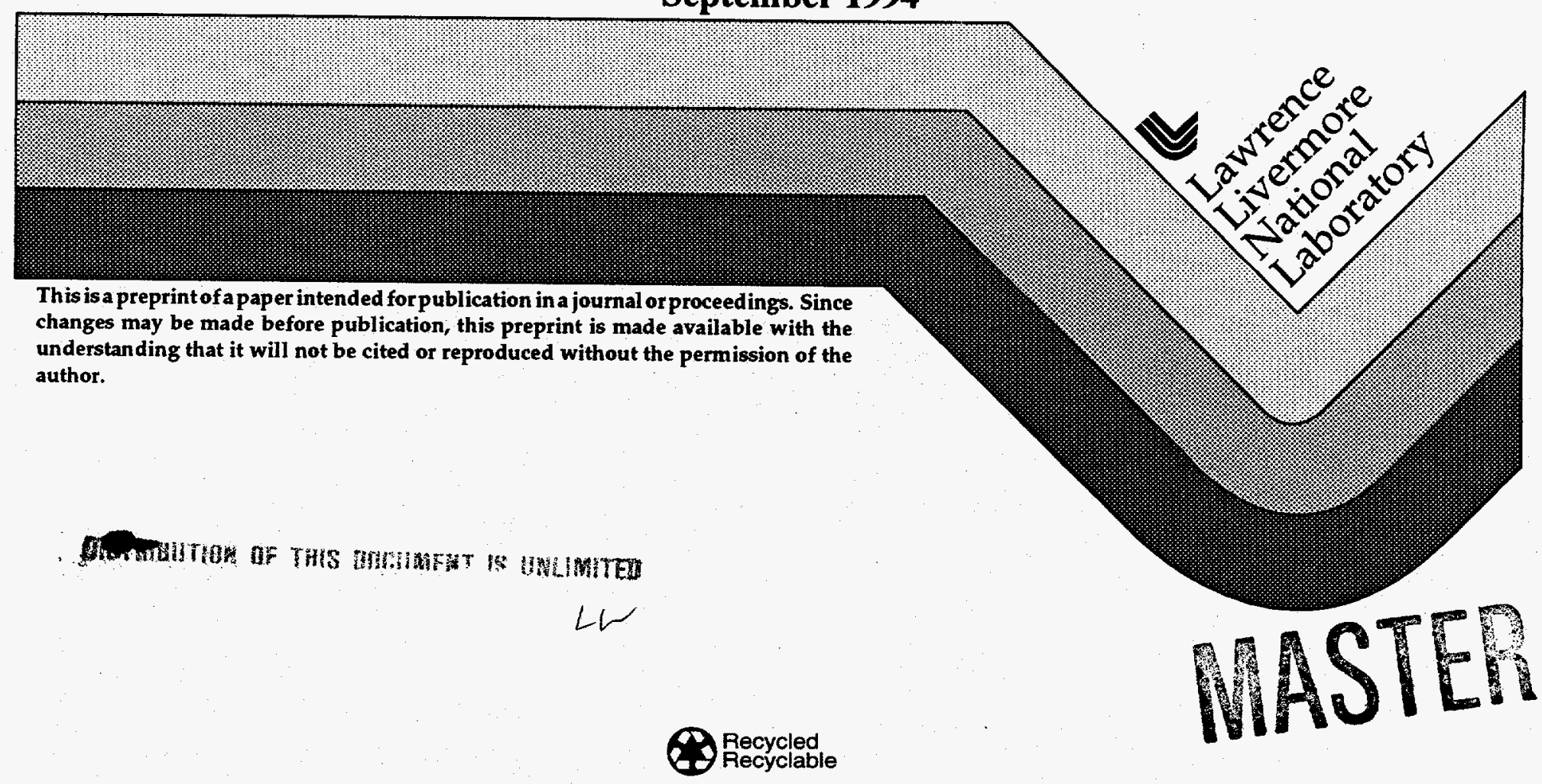




\section{DISCLAIMER}

This document was prepared as an account of work sponsored by an agency of the United States Government. Neither the United States Government nor the University of California nor any of their employees, makes any warranty, express or implied, or assumes any legal liability or responsibility for the accuracy, completeness, or usefulness of any information, apparatus, product, or process disclosed, or represents that its use would not infringe privately owned rights. Reference herein to any specific commercial products, process, or service by trade name, trademark, manufacturer, or otherwise, does not necessarily constitute or imply its endorsement, recommendation, or favoring by the United States Government or the University of California. The views and opinions of authors expressed herein do not necessarily state or reflect those of the United States Government or the University of California, and shall not be used for advertising or product endorsement purposes.

\section{DISCLAIMER}

This report was prepared as an account of work sponsored by an agency of the United States Government. Neither the United States Government nor any agency thereof, nor any of their employees, makes any warranty, express or implied, or assumes any legal liability or responsibility for the accuracy, completeness, or usefulness of any information, apparatus, product, or process disclosed, or represents that its use would not infringe privately owned rights. Reference herein to any specific commercial product, process, or service by trade name, trademark, manufacturer, or otherwise does not necessarily constitute or imply its endorsement, recommendation, or favoring by the United States Government or any agency thereof. The views and opinions of authors expressed herein do not necessarily state or reflect those of the United States Government or any agency thereof. 


\section{DISCLAIMER}

Portions of this document may be illegible in electronic image products. Images are produced from the best available original document. 
Unpublished manuscript prepared for the Dahlem Workshop on January 23, 1993. All rights

reserved by the author. No citation, abstracting, or any other usage is permitted.

\title{
CARBONACEOUS AEROSOLS INFLUENCING ATMOSPHERIC RADIATION : \\ BLACK AND ORGANIC CARBON
}

\author{
Joyce E. Penner \\ Global Climate Research Division \\ Lawrence Livermore National Laboratory \\ P.O. Box 808 \\ Livermore, CA 94550
}

\section{ABSTRACT}

Carbonaceous particles in the atmosphere may both scatter and absorb solar radiation. The fraction associated with the absorbing component is generally referred to as black carbon (BC) and is mainly produced from incomplete combustion processes. The fraction associated with condensed organic compounds is generally referred to as organic carbon (OC) or organic matter and is mainly scattering. Absorption of solar radiation by carbonaceous aerosols may heat the atmosphere, thereby altering the vertical temperature profile, while scattering of solar radiation may lead to a net cooling of the atmosphere/ocean system. Carbonaceous aerosols may also enhance the concentrations of cloud condensation nuclei. This paper summarizes observed concentrations of aerosols in remote continental and marine locations and provides estimates for the fine particle $(D<2.5 \mu \mathrm{m})$ source rates of both $O C$ and $B C$. The source rates for anthropogenic organic aerosols may be as large as the source rates for anthropogenic sulfate aerosols, suggesting a similar magnitude of direct forcing of climate. The role of $\mathrm{BC}$ in 
decreasing the amount of reflected solar radiation by oc and sulfates is discussed. The total estimated forcing depends on the source estimates for organic and black carbon aerosols which are highly uncertain. The role of organic aerosols acting as cloud condensation nuclei (CCN) is also described.

\section{INTRODUCTION}

Carbonaceous aerosols are those containing a carbon atom. Organic carbon $(O C)$ aerosols are the fraction of carbonaceous aerosols which contain compounds of carbon, while black carbon $(B C)$ is operationally defined as the absorbing component of aerosols. The sources of carbonaceous aerosols may be either primary or secondary. Primary sources are emitted as particles, secondary sources are emitted as gases and undergo photochemical transformation processes in the atmosphere before forming compounds which have low volatility and may condense to form an aerosol. In this paper, I emphasize the fraction of organics on particles $<2.5 \mu \mathrm{m}$ because most measurements refer to this size range and because climate forcing is mainly determined by this portion of the aerosol spectrum. The natural sources of fine particle carbonaceous aerosols include: (1) primary emissions of particles from natural fires, (2) primary emissions of plant materials injected through abrasion and by direct means, and (3) emissions of organic vapors, primarily terpenes, which form condensable organics after partial oxidation in the atmosphere. Anthropogenic sources include: (1) primary emissions from the burning of biomass, (2) primary emissions from the burning of fossil fuels, from industrial processes and from fugitive sources, 
and (3) emissions of volatile organics from fossil fuel burning and industrial processes which form condensable organics after partial oxidation. Organic compounds and carbonaceous compounds such as carbonate are also found in the particle emissions associated with sources of dust and sea-salt aerosol, but since most of the mass of these aerosols is associated with larger-sized particles, they will not be considered further here. Similarly, the mass concentrations of organic carbon associated with larger microorganisms can be substantial, but they are not of concern here. Sub-micrometer sized microorganisms such as viruses and mycoplasma are also present in the atmosphere, but little is known about their concentration (Duce et al., 1983) and emissions.

We have a great deal to learn and understand about the sources, cloud processing, and removal rates of carbonaceous aerosols, before a quantitative estimate of the anthropogenic and natural forcing by these aerosols is possible. In what follows, I first summarize methods for measuring the mass concentration of carbon and techniques for identifying the sources of the aerosol. Then, measured $\mathrm{OC}$ and $\mathrm{BC}$ concentrations in remote continental and ocean environments are summarized. In the fourth section of the paper, I provide estimates for the magnitude of the above-named source rates, differentiating between source estimates for $B C$ and $O C$. Carbonaceous aerosols may be present in the atmosphere as either an external or internal mixture. An external mixture is one in which the carbon compounds exist as discrete particles in the atmosphere. In an internal mixture, particles may have both carbon compounds and other chemical components existing within the same 
particle. Carbonaceous aerosol removal processes through dry and wet deposition depend on the size distribution, state of mixing, and chemical nature of the organic substance in the aerosol (i.e. whether it is soluble or insoluble in water). For the source estimates and analysis given below, I assume that the organic aerosol is internally mixed so that the lifetime of the accumulation-mode aerosol $(D=0.1-1.0 \mu \mathrm{m})$ is similar to that of other aerosol types (3-7 days; Penner et al., 1994a). The fifth section provides estimates of the direct forcing by anthropogenic organic carbon and black carbon aerosols, placing these estimates in the context of estimates for the direct forcing by anthropogenic sulfate aerosols. Finally, issues regarding the role of carbonaceous aerosols acting as cloud condensation nuclei are discussed.

\section{MEASUREMENT METHODS AND SOURCE IDENTIFICATION TECHNIQUES}

Most published concentrations of carbonaceous aerosols have been obtained through filter collection and analyzed by thermal volatilization and combustion methods. These methods of analysis give the mass concentration of total carbon, black carbon, and organic carbon (Novakov, 1981). Such analyses yield important information on total concentration, but are not very useful for determining the sources of the carbon. Because sources must be identified in order to attribute forcings to anthropogenic and natural causes, techniques which promise to yield information relevant to source identification will be reviewed here. 
Source identification has been attempted through measurement of the ${ }^{14} \mathrm{C} /{ }^{12} \mathrm{C}$ ratio in the sample, which allows one to identify the fraction of the carbon associated with fossil fuels relative to those from contemporary sources (Currie et al., 1983), (2) measurement of the ${ }^{13} \mathrm{C} /{ }^{12} \mathrm{C}$ ratio, which has been used to identify whether the aerosol is of marine (sea water) origin or whether it is combustion- or vegetation-derived (Cachier, 1989), and (3) extraction by an organic solvent such as benzene or ether followed by high resolution gas chromatography. This technique separates organics which are non-extractable and non-elutable from the elutable organics. The latter are characterized by identification of the resolved and unresolved fractions of the elutable organics. The unresolved fraction may be identified as a petroleum-derived component made up of branched and cyclic hydrocarbons, whereas the resolved fraction may be used to identify single compound peaks that may be classified further into diterpenoid acids, aromatic polycarboxylic acids, aliphatic dicarboxylic acids, n-alkenoic acids, n-alkanoic acids, and nalkanes (Rogge et al., 1993). The identification and quantification of the abundance of single compound peaks within the n-alkane, n-alkanol, and n-alkanoic acid groups is used to determine the carbon preference index (CPI) or the ratio of odd to even carbon number of the resolved groups. The carbon number of the maximum component can also be defined. Both the CPI and carbon number of the maximum component may be used to identify which fraction of each resolved group is derived from plants and which from anthropogenic sources (Simoneit, 1989). Determination of single compound concentrations or so-called "molecular" marker 
species (such as extended tricyclic terpanes, pristane and phytane, polynuclear aromatic hydrocarbons and various terpenoids) which are identified with particular sources can be used to identify the contribution of a particular source to a particular sample if the ratio of total carbon to molecular marker concentrations of the source category is known. Because only the extractable, elutable organics can be fully characterized, the molecular marker method cannot be applied to the remainder of the organic matter which is not extractable or which cannot be analyzed by GCMS. If the non-extractable and non-elutable fraction is large (and it is frequently as 'large as 50\% of the total organic mass in urban areas, Rogge et al., 1993), major uncertainties may remain concerning the magnitude of the anthropogenic and natural components of the total organic aerosol. High resolution mass spectrometry can also be used to identify a suite of components in an aerosol sample (Schuetzle, et al., 1975), but this method is difficult and costly and therefore has not been widely applied.

Hildemann et al. (1993) and Gray (1986) developed emissions inventories for particular source categories in Los Angeles and used models and measurements to identify the fraction of the organic aerosol that results from different source categories and from the oxidation of non-methane hydrocarbons in that area. Such studies emphasize the power of a combined measurement and modeling analysis, when source inventories can be independently developed. Unfortunately, no similar inventory analysis exists on a global scale and the observations needed to verify the inventories are 
very sparsely available. Therefore, in my estimates of source rates, I follow the methods used in the past (Duce, 1978; Jaenacke, 1978) which, unfortunately, derive at least one source category by differencing the total emissions (derived from budget considerations) with estimates of emissions from individual source categories. Below, I first present data on observed concentrations in order to estimate total source strengths.

\section{CONCENTRATIONS IN THE ATMOSPEERE}

Table 1 a presents a set of observed concentrations of organic carbon taken at remote continental sites in the United states. These are all sites that are in national parks in the United States and they provide estimates of concentrations in very clean continental conditions. Notably, in more rural locations, closer to population centers, the mean concentration of organic carbon aerosol is substantially larger than the concentrations listed in

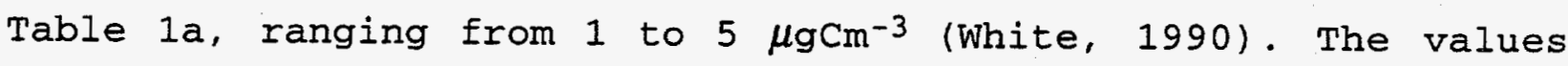
cited in Table la were converted from the organic matter concentrations reported in cahill et al. (1990) to $\mu \mathrm{gCm}^{-3}$ using their recommended conversion factor $(718$ of organic matter is assumed to be C). The total amount of organic matter associated with organic carbon depends, of course, on the molecular form of the organic compounds in the aerosol. Typical organic matter concentrations range from perhaps 1.2 to 1.5 times the concentration of carbon (e.g. Duce, 1978; Countess et al., 1980). In several different studies, the concentrations of organics in remote continental areas have been attributed primarily to anthropogenic sources (Trijonis et al., 1988; Mazurek et al., 
1991; and studies quoted in Trijonis, 1990). Trijonis (1990) estimates that perhaps $70 \%$ of the organic carbon present at remote locations in the United states is anthropogenic in origin. Table la also shows the measured mean concentration of sulfate aerosol at remote sites in the United States. Clearly, organic aerosols dominate or are equal to the sulfate component in the western United states, while sulfate dominates over organic carbon in the eastern United States.

Table $1 b$ presents a set of observed organic carbon concentrations taken at remote marine locations. In the few situations where both sulfate and organic carbon were simultaneously measured these are also listed. Unfortunately, many of the methods and size fractions from these various measurements were not identical. However, they provide evidence that Northern Hemisphere concentrations are generally higher that those in the Southern Hemisphere. Cachier et al. (1986; 1989) have studied the isotopic composition of particulate carbon in remote marine locales. They have shown that fossil and vegetative sources of particulate carbon are depleted in ${ }^{13} \mathrm{C}$ relative to sources from the ocean. Consideration of this fact together with the difference in concentrations in the Northern and Southern hemispheres, lead Cachier (1989) to conclude that much of the organic carbon in the remote marine Northern Hemisphere is of continental origin and most likely of anthropogenic origin. Because the ocean source of organic carbon mainly contributes to the super-micron size fraction of the aerosol concentration, the conclusion that the Northern Hemisphere marine organic carbon is primarily of 
anthropogenic origin fits with the notion that much of the organic aerosol in remote continental regions derives from anthropogenic sources (e.g. Trijonis, 1990).

Table 1c presents observed black carbon concentrations from remote locations. Again, unfortunately the methods and size fractions of the reported concentrations were not identical. Black carbon is mainly from combustion and, therefore, results almost entirely from anthropogenic sources. (Note, however, that some organic compounds can absorb radiation also and would operationally be detected as black carbon in measurements that use reflection from or transmission through a filter to detect black carbon). Because black carbon mainly absorbs solar radiation, it is important to distinguish the fraction of the total aerosol associated with black carbon. Below, after first estimating the source strength for organic and black carbon aerosols, I estimate the forcing associated with anthropogenic organic matter and black carbon. Anthropogenic sulfate forcing is also estimated in order to put the contribution of organics into context.

\section{SOURCES AND SOURCE STRENGTHS OF CARBONACEOUS AEROSOLS}

The source strengths for organic and black carbon aerosols are not well known. A common method for quantifying the total source strength of carbonaceous aerosols is to quantify the ambient concentrations of total carbon and to divide these by an estimate of the carbon aerosol lifetime (which, for an internally mixed aerosol is taken to be similar to the lifetimes of other, submicron aerosols, e.g. 3-7 days). In the following, where possible, 
different source strengths from different emissions categories have been estimated separately from known fuel usages and emissions factors and from known volatile emissions and estimates of gas to particle conversion efficiencies. Little is known about the emissions of biogenic particles, however, so these are assigned source strengths by differencing the separate individual source strengths from the estimated total source strength. This technique is less than satisfactory, since no independent means of quantification is available. In the future, it seems important to try to quantify this fraction directly by resolving the known concentrations with estimates of emissions from each source type and by verifying the strength of the biogenic component at different locales through, for example, molecular marker techniques, CPI methods, and isotopic characterization. Unfortunately, only a few such measurements are presently available and measurements that would allow such quantification on a global basis do not presently exist.

Table 2 provides estimates of the source strengths for organic and black carbon aerosols from the major source categories. These estimates apply to the aerosol fraction with $D<2.5 \mu \mathrm{m}$, since most measurement and most emission factors apply to this size range. However, for climate forcing calculations it is important to quantify the size-segrated emissions of $O C$ and $B C$, because the scattering and absorption coefficients are largest for particles with $D<1.0 \mu \mathrm{m}$.

In Table 2, the estimates for organic matter are for total organic matter, which, as noted above, ranges from 1.2 to 1.5 


\section{Joyce E. Penner}

times the organic carbon content of the aerosols. The estimates for black carbon are given in Tg C/Yr. The estimates in Table 2 are derived as follows. Smoke aerosols from biomass burning associated with savanna fires and agricultural waste burning were estimated using an emission factor of $5 \mathrm{~g}$ of organic matter per $\mathrm{kg}$ of fuel burned together with the inventories for these fuels from Andreae (1991). This emission factor is consistent with that measured for low moisture content rice straw (Goss and Miller, 1973) and for emissions from Cerrado (Ward et a1., 1991). To estimate emissions in regions affected by forest clearing, I use an emission factor of $16 \mathrm{~g}$ per $\mathrm{kg}$ of fuel (Penner et al., 1991). The sources identified with urban activities (fossil and wood fuel burning, industrial processes, and fugitive emissions) were estimated by scaling estimates for the total black carbon source (which range from $5 \mathrm{TgCyr}^{-1}$ to $25 \mathrm{TgCyr}^{-1}$; see Penner et al., 1994a) by measured ratios of organic matter to black carbon matter in urban areas. Since the latter ratio varies from region to region, this latter estimate is very uncertain. The source strength of secondary organics from anthropogenic sources is tentatively estimated from the ratio of secondary organics to total organic mass defined in studies of the Los Angeles organic aerosol. This would provide a lower bound if gas-to-particle conversion processes continue downwind of the urban area (Hildemann et al., 1993; Rogge et al., 1993).

The estimates of anthropogenic black carbon emissions were

derived from the source estimates in Penner et al. (1993). Table 2 Iists the total black carbon source strength from all sources 


\section{Joyce E. Penner}

(savanna, forest, agricultural, and fuel wood burning, together with estimates of the source from diesel and coal burning). Approximately $6 \mathrm{Tg} \mathrm{C} / \mathrm{yr}$ derives from diesel and coal burning, while an addition $12 \mathrm{Tg}$ C/Yr derives from biomass burning. The estimates for coal burning are considerably higher than previous estimates because of the consideration of coal use in the domestic sector and its higher emission factor (see Penner et al., 1993; compare Turco et al., 1983 whose total emissions of BC from fossil fuel sources ranged from 2.0 to $8.5 \mathrm{Tg} / \mathrm{yr}$ and Andreae, 1991 whose emissions of $\mathrm{BC}$ from biomass burning totaled $19 \mathrm{Tg} / \mathrm{Yr}$ ).

The natural sources of organic carbon aerosols were estimated as follows: Smoke aerosols from wild fires were estimated from estimates of the amount of fuel burned in forest wild fires (Logan et al., 1981) using the emission factor of $16 \mathrm{~g}$ per $\mathrm{kg}$ fuel noted above for forest burning. Black carbon emissions from natural fires were assumed to be about $10 \%$ of the organic emissions. Secondary organics formed from the oxidation of terpenes used a factor of $10 \%$ (Pandis et al., 1991) to convert total terpene emissions (which were

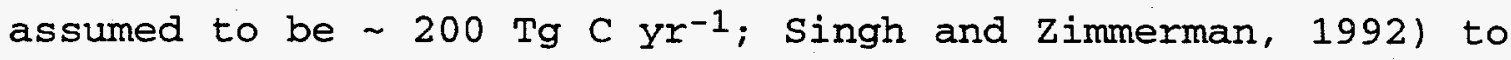
organic aerosol source strengths. An additional factor of 1.4 converted these carbon yields to total organic matter. The marine organic source for sub-micron sized aerosol is assumed to be negligible, based on the measured fraction of n-alkanes in marine aerosols (Eichman et al., 1980) and sizefractionated isotopic studies of marine aerosol sources (Cachier, 1989). The primary emissions of plant and biogenic 
materials is estimated as the difference between the above sources and the total source of organic matter in aerosols. Following Duce (1978), the latter is estimated assuming a land-average concentration of $1.5 \mu \mathrm{gCm}^{-3}$ in both hemispheres and Northern and Southern Hemisphere ocean concentrations of $0.5 \mu \mathrm{gCm}^{-3}$ and $0.2 \mu \mathrm{gCm}^{-3}$, respectively (see Table 1), together with an assumed scale height of $6 \mathrm{~km}$, a lifetime ranging from 3 to 7 days, and conversion of carbon mass to organic matter using a factor of 1.4. This, together with the particle emissions estimated for all of the above categories yields an estimate for the primary emissions of biogenic material of $56 \mathrm{Tg}$ organic matter $\mathrm{yr}^{-1}$. This estimate is clearly very uncertain and subject to considerable error. In fact, Cachier et al. (1986) imply that the sources listed in Table 2 are incomplete. They argue that much of the marine organic aerosol must be secondary in origin, based on the observed decreases in $210 \mathrm{~Pb}$ (which is derived from $222 \mathrm{Rn}$ emitted over land areas) relative to those for organic carbon. The inference that much of the marine organic aerosol is secondary is also consistent with the measured size distributions of marine organic matter (Novakov and Penner, 1993; Cachier, 1986). The inference requires an additional source of organic material that represents either a slow conversion from land-based sources or unknown oceanic sources of carbon. Further measurements are needed to clarify the magnitude and nature of this source. 


\section{Joyce E: Penner}

\section{FORCING BY ANTHROPOGENIC CARBONACEOUS AEROSOLS}

For illustrative purposes, I employ the box model of Charlson et al. (1991) to estimate the effect of carbonaceous aerosols on reflected solar radiation. The results of this model are between a factor of 2 and 4 larger than the results of more detailed radiative calculations (compare Charlson et al., 1991; Kiehl and Briegleb, 1993), but may be used to provide a sense of the order of magnitude and of the relative importance of different aerosol components. Here, for comparison purposes, I estimate the forcing by anthropogenic sulfate aerosols, anthropogenic organic carbon aerosols and anthropogenic black carbon aerosols.

For an aerosol layer with reflectivity $r$ and transmissivity $t$, the change in the reflected solar radiation is:

$$
\Delta \mathrm{F}_{\mathrm{r}}=1 / 2 \mathrm{Q}_{0} \mu_{0} \mathrm{~T}_{\mathrm{a}}^{2}\left(1-\mathrm{A}_{\mathrm{c}}\right) \Delta \mathrm{R}_{\mathrm{as}}
$$

where $Q_{0}$ is the solar constant, $\mu_{0}$ is the cosine of the zenith angle, $\mathrm{T}_{a}^{2}$ is the transmissivity of the overlying layer, $\left(1-A_{c}\right)$ is the clear sky fractional area, and $\Delta R_{a s}$ is the change in reflectivity of the surface/aerosol system. For an absorbing aerosol, the relation:

$$
\Delta \mathrm{R}_{\mathrm{as}}=r+t^{2} \alpha_{\mathrm{s}} /\left(1-\alpha_{\mathrm{s}} r\right)-\alpha_{\mathrm{s}}
$$

may be employed (see Twomey, 1977), where $\alpha_{S}$ is the albedo of the surface, and the reflectivity and transmissivity of the aerosol layer is given by:

$$
r=\left(1-e^{-\delta / \mu_{o}}\right) \beta \omega_{0}
$$




$$
t=e^{-\delta / \mu_{0}}+\left(1-e^{-\delta / \mu_{0}}\right)(1-\beta) \omega_{0}
$$

In these expressions $\beta$ is the globally averaged fraction of upscattered radiation, which we set equal to 0.3 (see Penner et al., 1992), $\omega_{0}$ is the aerosol single scattering albedo, and $\delta$ is the aerosol optical depth. The single scattering albedo is the ratio of the specific scattering coefficient and the specific extinction coefficient of the aerosol. The optical depth of the layer is the product of the column abundance of aerosol ( $\mathrm{gm}^{-2}$ ) times the specific extinction coefficient $\left(\mathrm{m}^{2} \mathrm{~g}^{-1}\right)$. $\omega_{0}$ can be estimated from estimated mass concentrations of the principal light scattering (i.e. organic matter and sulfate) and absorbing (i.e. black carbon) anthropogenic aerosol components and their respective specific scattering and absorption coefficients $k_{s}$ and $k_{\mathrm{a}}$ (also known as the scattering and absorption efficiencies). These, of course, may vary depending on the size distribution of each component within the aerosol, whether it is internally or externally mixed, and whether water or other components are associated with the aerosol. In the following, however, I employ a single numerical value for each chemical component, consistent with previous analyses (sloan et al., 1991).

The specific absorption coefficient for black carbon $k_{a}(B C)$ is defined as the ratio of the absorption coefficient (in $\mathrm{m}^{-1}$ ) to $\mathrm{BC}$ mass concentration per volume of air (in $\mathrm{g} \mathrm{m}^{-3}$ ). Results from several sets of measurements as well as theoretical estimates using Mie theory show that the $k_{\mathrm{a}}(\mathrm{BC})$ values for urban and rural ambient aerosols range from -8 to 12 at visible wavelengths. Below, I adopt a value of $10 \mathrm{~m}^{2} \mathrm{~g}^{-1}$ (with an uncertainty of about 
20\%). This value is also typically used to convert measured aerosol absorption coefficients to BC mass concentration. Black carbon may also scatter radiation. Here, I adopt the value $k_{S}(B C)=$ $2.0 \mathrm{~m}^{2} \mathrm{~g}^{-1}$ (Sloan et al., 1991). Organic carbon is mainly scattering, with $\mathrm{k}_{\mathrm{S}}(O C)=5 \mathrm{~m}^{2} \mathrm{~g}^{-1}$ (Sloan et al., 1991) increasing to perhaps $8.5 \mathrm{~m}^{2} \mathrm{~g}^{-1}$ at high relative humidity in the case of organics from biomass burning (Penner et al., 1992). For sulfate, $\mathrm{k}_{\mathrm{s}}\left(\mathrm{SO}_{4}^{2-}\right), I$ adopt the two scattering values 5 and $8.5 \mathrm{~m}^{2} \mathrm{~g}^{-1}$ for $\mathrm{k}_{\mathrm{s}}\left(\mathrm{SO}_{4}^{2-}\right)$ corresponding to low and.high relative humidity (Charlson et al., 1991).

The sulfate, organic carbon and black carbon column abundances may be estimated from a simple box model:

$$
\begin{aligned}
& \mathrm{M}_{\mathrm{SO}_{4}}^{2-}=\mathrm{F}_{\mathrm{SO}_{4}^{2-}}^{2-} \tau_{\mathrm{SO}_{4}^{2-}}^{2 \mathrm{~A}} \\
& \mathrm{M}_{\mathrm{OC}}=\mathrm{F}_{\mathrm{OC}} \quad \tau_{\mathrm{OC}} / \mathrm{A} \\
& M_{B C}=F_{B C} \quad \tau_{B C} / A,
\end{aligned}
$$

where $\dot{\mathrm{F}}_{\mathrm{SO}_{4}}^{2-}, \mathrm{F}_{\mathrm{OC}}$ and $\mathrm{F}_{\mathrm{BC}}$ are the average source strengths of anthropogenic $\mathrm{SO}_{4}^{2-}$, organic matter, and $\mathrm{BC}$ emissions, $\tau_{\mathrm{SO}_{4}^{2-}}^{2-} \tau_{\mathrm{OC}}$ and $\tau_{\mathrm{BC}}$ are the mean fine-particle lifetimes (estimated as 5 days), and $\mathrm{A}$ is the area of the earth. The source of $\mathrm{SO}_{4}^{2-}$ is equivalent to about half the anthropogenic sulfur source, $66 \mathrm{Tg}$ (as S) $\mathrm{yr}^{-1}$ (see Penner et al., 1994b) giving a column sulfate abundance of $2.7 \times 10^{-3} \mathrm{gm}^{-2}$. Using the $\mathrm{OC}$ and $\mathrm{BC}$ source rates from Table 2, $100 \mathrm{Tg}$ organic matter $\mathrm{yr}^{-1}$ and $18 \mathrm{Tg} . \mathrm{C} \mathrm{yr}^{-1}$, respectively, the organic matter and BC column abundances are estimated as $2.7 \times 10^{-3}$ and $5 \times 10^{-4} \mathrm{gm}^{-2}$. 
The model may now be used to estimate scattering by anthropogenic sulfate and anthropogenic organic matter. Assuming a typical land surface albedo $\left(\alpha_{s}=0.19\right)$, and assuming an aerosol single scattering albedo of 1.0 , the forcing by sulfate aerosol is calculated to range from $-0.56 \mathrm{Wm}^{-2}$ to $-0.94 \mathrm{Wm}^{-2}$ depending on whether the smaller or larger value for the sulfate aerosol scattering coefficient is used. If anthropogenic organic aerosols are considered as well, with $\omega_{0}=1.0$, the range increases from $-1.10 \mathrm{Wm}^{-2}$ to $-1.48 \mathrm{Wm}^{-2}$. Thus, consideration of the scattering by organic matter increases anthropogenic aerosol forcing by up to a factor of 2. To define the effect of BC, we must estimate the single scattering albedo of a mixed aerosol consisting of sulfate, organic carbon and black carbon. Here, I use the product of the column concentration of scattering and absorbing components times the respective specific scattering and absorption coefficients $\mathrm{k}_{\mathrm{s}}$ and $\mathrm{k}_{\mathrm{a}}$ :

$$
\omega_{0}=\frac{\left[\mathrm{k}_{\mathrm{s}}\left(\mathrm{SO}_{4}^{2-}\right) \times \mathrm{M}_{\mathrm{SO}_{4}^{2-}}+\mathrm{k}_{\mathrm{s}}(\mathrm{OC}) \times \mathrm{M}_{\mathrm{OC}}+\mathrm{k}_{\mathrm{s}}(\mathrm{BC}) \times \mathrm{M}_{\mathrm{BC}}\right]}{\left[\mathrm{k}_{\mathrm{s}}\left(\mathrm{SO}_{4}^{2-}\right) \times \mathrm{M}_{\mathrm{SO}_{4}^{2-}}+\mathrm{k}_{\mathrm{s}}(\mathrm{OC}) \times \mathrm{M}_{\mathrm{OC}}+\mathrm{k}_{\mathrm{s}}(\mathrm{BC}) \times \mathrm{M}_{\mathrm{BC}}+\mathrm{k}_{\mathrm{a}}(\mathrm{BC}) \times \mathrm{M}_{\mathrm{BC}}\right]}
$$

If we adopt the above values for $k_{s}\left(S O_{4}^{2-}\right), k_{s}(O C), k_{a}(B C)$ and $k_{s}(B C)$, then the albedo of the average anthropogenic sulfate/carbonaceous aerosol layer is $\omega_{0}=0.88$ assuming the high sulfate scattering efficiency. Using the lower scattering efficiency gives an average anthropogenic aerosol single scattering albedo $\omega_{0}=0.85$. Note that this estimate for $\omega_{0}$ may be lower than estimates derived from ambient measurements. Ambient measurements of aerosol single scattering albedo contain natural aerosol components as well as the anthropogenic components considered here. Also ambient 
measurements are expected to vary by region, mainly reflecting the proximity of BC sources. The total anthropogenic optical depths $\delta$ corresponding to these two values for sulfate are 0.043 and 0.033 , respectively. Using the box model estimates for $\delta$ and $\omega_{0}$ noted above, the average reflection of $-1.48 \mathrm{wm}^{-2}$ for anthropogenic sulfate and organic matter alone is reduced to $-1.13 \mathrm{Wm}^{-2}$ for the higher scattering efficiency and from $-1.10 \mathrm{Wm}^{-2}$ to $-0.76 \mathrm{Wm}^{-2}$ for the lower. Thus the average reflection by anthropogenic sulfate and organic aerosols is decreased by between 20 and $30 \%$ when absorption by black carbon is considered. A large uncertainty is associated with this result, however, because of uncertainties associated with source strengths and concentrations in the atmosphere. To illustrate this uncertainty, Figure 1 shows the change in reflected solar radiation for different levels of oc and BC emissions as predicted by the simple box model. Two cases are considered. One with $\mathrm{k}_{\mathrm{s}}=5 \mathrm{~m}^{2} \mathrm{~g}^{-1}$, for low relative humidity and one with $\mathrm{k}_{\mathrm{s}}=8.5 \mathrm{~m}^{2} \mathrm{~g}^{-1}$ at high relative humidity (relevant for carbonaceous aerosols from biomass burning). As shown there, the change in reflected solar radiation is sensitive to the relative emissions of $O C$ and $B C$ as well as to their total amount. This fact emphasizes the need for a better quantification of the forcing by carbonaceous aerosols (Penner et al., 1994a). Additionally, the forcing would be expected to vary significantly depending on actual local conditions. The simple model shows, however, the importance of including both $O C$ and $B C$ in any estimate of the direct forcing by anthropogenic aerosols. 


\section{THE ROLE OF ORGANIC AEROSOLS IN CCN PRODUCTION}

Indirect forcing of climate results from an increase in the number of particles which may act as cloud condensation nuclei (CCN). If $\mathrm{CCN}$ concentrations are increased, droplet concentrations may increase producing clouds that are more highly reflective of solar radiation. The indirect forcing of climate by organic aerosols is even more difficult to estimate than the direct forcing, but may be important. For example, Novakov and Penner (1993) noted that the contribution of organic aerosols to cloud condensation nuclei or CCN concentrations may be larger than the ratio of the respective masses of organic carbon to sulfate aerosol if the organic carbon is associated with sizes which determine the CCN number concentration, while the sulfate mass is concentrated at larger particle sizes. Anthropogenic organic aerosols in remote locations are presumably present as internally mixed aerosols. Thus, they are present together with salts such as ammonium sulfate in the same aerosol particle. In some cases the organic component may be present, as a coating which formed on a pre-existing aerosol particle. If the organics deposited in this way are hydrophobic, the deposition of an organic coating may cause a previously hydrophilic particle to become hydrophobic. Then the deposition of organics would act to slow evaporation and condensation, thereby decreasing the number of CCN. However, surfactant organic molecules have both a hydrophilic and a hydrophobic part. One study has shown that when an organic surfactant was deposited onto previously hydrophobic particles, the surfactant molecules preferentially oriented their hydrophilic 
part outward, thus actually increasing the hygroscopicity of the particles (Andrews and Larson, 1993).

If the organic aerosol is present as the pre-existing particle, the condensation of sulfuric acid vapor to its surface may render a previously hydrophobic particle hydrophilic, thereby increasing CCN concentrations (Novakov and Penner, 1993). Thus, in some cases the organics may increase the number of particles which act as cloud condensation nuclei while in other cases they may decrease the number of $\mathrm{CCN}$. Which process dominates, depends in part on the relative role of secondary versus primary organics. If most organic particles are primary, as deduced from studies in urban areas (Hildemann, et al. 1993), one might safely conclude that most particles in remote areas are not covered by an organic surfactant. On the other hand, as noted above, some evidence suggests that the concentrations of organics in marine locales are mainly secondary. If true, this may imply that organics could decrease the production of $\mathrm{CCN}$ by anthropogenic sulfate aerosols.

\section{CONCLUSIONS AND OUTSTANDING ISSUES}

The anthropogenic sources of organic aerosols appear to be similar in magnitude to the anthropogenic sources of sulfate aerosols. This, together with the assumption that the scattering efficiency of organic matter is similar in magnitude to that of sulfate leads to the conclusion that the direct forcing by anthropogenic organic aerosols is of the same order as the direct forcing by anthropogenic sulfate aerosols. However, the presence of $B C$ in the aerosol may decrease considerably the overall 
scattering of the aerosol layer. The quantitative effect of organic and black carbon aerosols is subject to considerable uncertainty, however, primarily because the emissions of these aerosols are not well quantified (see also Penner et al., 1994a). Also, anthropogenic emissions of organic aerosols may either enhance or decrease the number of aerosol particles from anthropogenic sulfur emissions which would otherwise act as cloud condensation nuclei, making estimates for the magnitude of the indirect forcing by anthropogenic aerosols highly uncertain. Measurements of aerosol characteristics at a variety of remote continental and oceanic locations together with models developed to simulate multi-component aerosol dynamics are needed to quantify the role of these aerosols in climate change.

\section{Acknowledgments}

This work was performed under the auspices of the U.S. Department of Energy by Lawrence Livermore National Laboratory under Contract No. W-7405-Eng-48. Partial support was provided the DOE Quantitative Links and ARM Programs and the NASA Aerosol Program. I am grateful to $T$. Novakov and to an unknown reviewer for useful comments on the first version of this manuscript. 


\section{REFERENCES}

Andreae, M.O. 1982. Marine aerosol chemistry at Cape Grim, Tasmania, and Townsville, Queensland. J. Geophys. Res. 87:88758885 .

Andreae, M.O. 1983. Soot carbon and excess fine potassium: longrange transport of combustion-derived aerosols. Science 220:11481151.

Andreae, M.O., T.W. Andreae, R.J. Ferek, and H. Raemdonck. 1984. Long-range transport of soot carbon in the marine atmosphere. Sci. Total Environ. 36:73-80.

Andreae, M.O. 1991. Biomass burning: Its history, use, and distribution and its impact on environmental quality and global climate. In: Global Biomass Burning, ed. by J. Levine, pp. 3-21. Cambridge, MA: MIT press.

Andrews, E. and S.M. Larson. 1993. Effect of surfactant layers on the size changes of aerosol particles as a function of relative humidity. Environmental Science and Technology 27:857-865.

Barger, W.R., and W.D. Garrett. 1976. Surface active organic material in air over the Mediterranean and over the eastern equatorial Pacific. J. Geophys. Res. 81:3151-3157.

Cachier, H. 1989. Isotopic characterization of carbonaceous aerosols. Aerosol Science and Technology 10:379-385. 
Cachier, H., P. Buat-Ménard, M. Fontugne, and R. Chesselet. 1986. Long-range transport of continentally-derived particulate carbon in the marine atmosphere: Evidence from stable carbon isotope studies. Tellus 38B:161-177.

Cahill, T.A., R.A. Eldred, L.K. Wilkinson, B.P. Perley, and W.C. Malm. 1990. Spatial and temporal trends of fine particles at remote U.S. sites. In: Proceedings of the 83 rd Annual Meeting and Exhibition of the Air and Waste Management Association. Pittsburgh, PA, pp. 24-29.

Charlson, R.J., J. Langner, H. Rodhe, C.B. Leovy, and S.G. Warren. 1991. Perturbation of the Northern Hemisphere radiative balance by backscattering from anthropogenic sulfate aerosols. Tellus 43AB : $152-163$.

Chesselet, R., M. Fontugne, P. Buat-Ménard, U. Ezat, and C.E. Lambert. 1981. The origin of particulate organic carbon in the marine atmosphere as indicated by its stable carbon isotopic composition. Geophys. Res. Lett. 8:345-348.

Clarke A.D. 1989. Aerosol light absorption by soot in remote environments. Aerosol Sci. and Technol. 10:161-171.

Countess, R.J., G.T. Wolff, and S.H. Cadle. 1980. J. Air Pollut. Control Assoc. 30:1194-1200.

Currie, I., A., G.A. Klouda, R.E. Continetti, I.R. Kaplan, W.W. Wong, T.G. Dzubay, and R.K. Stevens. 1983. On the origin of carbonaceous particles in American cities. Results of radiocarbon dating and chemical characterization. Radiocarbon 25:603-614. 
Duce, R.A. 1978. Speculations on the budget of particulate and vapor phase non-methane organic carbon in the global troposphere. Pure and Applied Geophysics 116:244-273.

Duce, R.A., V.A. Mohnen, P.R. Zimmerman, D. Grosjean, W. Cautreels, R. Chatfield, R. Jaenicke, J.A. Ogren, E.D. Pellizzari, and G.T. Wallace. 1983. Organic material in the global troposphere. Rev. of Geophys. and Space Phys. 21:921-952.

Eichmann, R., P. Neuling, G. Ketsiridis, J. Hahn, R. Jaenicke, and C. Junge. 1979. N-alkane studies in the troposphere. I-Gas and particulate concentrations in North Atlantic air. Atmos. Environ. $13: 587-599$.

Eichmann, R., G. Ketsiridis, G. Schebeske, R. Jaenicke, J. Hahn, P. Warneck, and C. Junge. 1980. N-alkane studies in the troposphere. II-Gas and particulate concentration in Indian Ocean air. Atmos. Environ. 14:695-703.

Goss, J.R., and G.E. Miller, Jr. 1973. Study of abatement methods and meteorological conditions from field burning of rice straw. Final Report, California Air Resources Board Project 1-101-1 and ARB 2113, University of California, Davis.

Gray, H.A. 1986. Control of atmospheric fine primary carbon particle concentrations. Environmental Quality Laboratory Report No. 23, California Institute of Technology. Pasadena, California.

Hansen A.D.A., B.A. Bodhaine, E.G. Dutton and R.C. Schnell. 1988. Aerosol black carbon measurements at the South pole: Initial results 1986-1987. Geophys. Res. Lett. 15:1193-1196. 
Hansen A.D.A., R.S. Artz, A.A.P. Pszenny and R.E. Larson. 1990. Aerosol black carbon and radon as tracers for air mass origin over the Atlantic Ocean. J. Global Biogeochemical Cycles 4:189-199.

Heintzenberg J. 1982. Size-segregated measurements of particulate elemental carbon and aerosol light absorption at remote arctic locations. Atmos. Env. 16:2461-2469.

Hidy, G.M., P.K. Mueller, H.H. Wang, J. Karney, S. Twiss, M. Imada, and A. Alcocer. 1974. Observations of aerosols over southern California coastal waters. J. Appl. Meteor. 13:96-107.

Hildemann, L.M., G.R. Cass, M.A. Mazurek, and B.R.T. Simoneit. 1993. Mathematical modeling of urban organic aerosol: Properties measured by high-resolution gas chromatography. Environ. Sci. Technol. $27: 2045-2055$.

Hoffman, E.J. and R.A. Duce. 1974. The organic carbon content of marine aerosols collected on Bermuda. J. Geophys. Res. 79:44744477 .

Hoffman, E.J. and R.A. Duce. 1977. Organic carbon in marine atmospheric particulate matter: Concentration and particle size distribution. Geophys. Res. Lett. 4:449-452.

Ketseridis, G., J. Hahn, R. Jaenicke, and C. Junge. 1976. The organic constituents of atmospheric particulate matter. Atmos. Environ. 10:603-610. 
Kiehl, J.T., and B.P. Briegleb. 1993. The relative role of sulfate aerosols and greenhouse gases in climate forcing. Science 260:311314.

Jaenicke, R. 1978. The role of organic material in atmospheric aerosols. Pure and Applied Geophysics 116: 283-292.

Logan, J.A., M.J. Prather, S.C. Wofsy, and M.B. McElroy. 1981. Tropospheric chemistry: A global perspective. J. Geophys. Res. $86: 7210-7254$.

Malm, W.C., J.F. Sisler, D. Huffman, R.A. Eldred and T.A. Cahill. 1994: Spatial and seasonal trends in particle concentration and optical extinction in the United States, J. Geophys. Res. 99:13471370 .

Mazurek, M.A., G.R. Cass, and B.R.T. Simoneit. 1991. Biological input to visibility-reducing aerosol particles in the remote arid southwestern United States. Environ. Sci. Technol. 25:684-694.

Novakov, T. 1981. Microchemical characterization of aerosols, in Nature, Aim and Methods of Microchemistry. In: Proceedings of the 8 th International Microchemical Symposium, Graz, Austria, August 25-30, 1980, ed. H. Malissa, M. Grasserbauer, and R. Belcher, pp. 141165. Springer-Verlag, wien.

Novakov, T. and J.E. Penner. 1993. Large contribution of organic aerosol to cloud-condensation-nuclei concentrations. Nature $365: 823-826$. 
Pandis, S.N., S.E. Paulson, J.H. Seinfeld, and R.C. Flagan. 1991. Aerosol formation in the photooxidation of isoprene and b-pinene. Atmospheric Environment 25A:997-1008.

Penner, J.E., S.J. Ghan, and J.J. Walton. 1991. The role of biomass burning in the budget and cycle of carbonaceous soot aerosols and their climate impact. In: Global Biomass Burning ed. J. Levine, pp. 387-393. Cambridge, MA: MIT press.

Penner, J.E., R. Dickinson and C. O'Neill. 1992. Effects of aerosol from biomass burning on the global radiation budget. Science. $256: 1432-1434$.

Penner, J.E., H. Eddleman and T. Novakov. 1993. Towards the development of a global inventory of black carbon emissions. Atmos. Environ. 27A:1277-1295.

Penner, J.E., R.J. Charlson, J.M. Hales, N. Laulainen, R. Leifer, T. Novakov, J. Ogren, L.F. Radke, S.E. Schwartz, and I. Travis. 1994a. Quantifying and minimizing uncertainty of climate forcing by anthropogenic aerosols. Bulletin of the American Meteorological Society $75: 375-400$.

Penner, J.E., C.A. Atherton, and T. Graedel. 1994b. Global emissions and models of photochemically active compounds, to be published in Global Atmospheric-Biospheric Chemistry: The First IGAC Scientific Conference, OHOLO Conference series Books, ed. R. Prinn, Plenum Publishing, N.Y. 
Rosen H., A.D.A. Hansen and T. Novakov. 1984. Role of graphitic carbon particles in radiative transfer in the arctic haze. Sci. Total Environ. $36: 103-110$.

Rogge, W.F., M.A. Mazurek, L.M. Hildemann, G.R. Cass, and B.R.T. Simoneit. 1993. Quantification of urban organic aerosols at a molecular level: Identification, abundance and seasonal variation. Atmospheric Environment 27A:1309-1330.

Schuetzle, D., D. Cronn, A.L. Crittenden, and R.J. Charlson. 1975. Molecular composition of secondary aerosol and its possible origin. Environmental Science and Technology 9:838-845.

Simoneit, B.R.T. 1989. Organic matter of the troposphere-V: Application of molecular marker analysis to biogenic emissions into the troposphere for source reconciliations. Journal of Atmospheric Chemistry 8:251-275.

Singh, H.B. and P.B. Zimmerman. 1992. Atmospheric distribution and sources of nonmethane hydrocarbons. In: Gaseous pollutants: Characterization and Cycling, ed. J.O. Nriagu, pp. 177-235. John Wiley \& Sons, Inc.

Sloane, C.S., J. Watson, J. Chow, and L. Pritchett. 1991. Sizesegregated fine particle measurements by chemical species and their impact on visibility impairment in Denver, Atmos. Environ. 25A : 1013-1024.

Trijonis, J.C., M. McGown, M. Pitchford, D. Blumenthal, P. Roberts, W. White, E. Macias, R. Weiss, A. Waggoner, J. Watson, J. Chow, and R. Flocchini. 1988. RESOLVE project final report: 
Visibility conditions and causes of visibility degradation in the Mojave Desert of California. NWC TP 6869, Naval Weapons Center. China Lake, CA.

Trijonis, J.C. 1990. Characterization of natural background aerosol concentrations. Appendix A, in Visibility: Existing and Historical Conditions-Causes and Effects. Acidic Deposition state of Science and Technology Report 24, National Acid Precipitation Assessment Program, Government Printing Office, Washington, D.C.

Twomey, S. 1977. Atmospheric Aerosols. Elsevier, Amsterdam, 289pp.

Turco, R.P., O.B. Toon, R.C. Whitten, J.B. Pollack, and P. Hamill. 1983. The global cycle of particulate elemental carbon: A theoretical assessment. In: Precipitation Scavenging, Dry Deposition, and Resuspension, ed. H.R. Pruppacher, R.G. Semonin, and W.G.N. Slinn, pp. 1337-1351. New York: Elsevier Science Publishing Co., Inc.

Ward, D.E., A.W. Setzer, Y.J. Kaufman, and R.A. Rasmussen. 1991: Characteristics of smoke emissions from biomass fires of the Amazon region-BASE-A experiment. In: Global Biomass Burning, ed. J. Levine, pp. 394-402. Cambridge, MA: MIT press.

Whelpdale D.M., Keene W.C., Hansen A.D.A., and Boatman J. 1987. Aircraft measurements of sulfur, nitrogen, and carbon species during WATOX-86. Global Biogeochemical Cycles 1:357-368.

White, $W$. 1990. The contribution of fine particle scattering to total extinction. Sections 4.1-4.4. In: Visibility: Existing and Historical Conditions-Causes and Effects. Acidic Deposition state 


\section{Joyce E: Penner}

of Science and Technology Report 24, pp. 85-102. National Acid Precipitation Assessment Program, Government Printing office, Washington, D.C.

Wolff, G.T., M.S. Ruthkosky, D.P. Stroup, P.E. Korsog, M.A. Ferman, G.J. Wendel, and D.H. Stedman. 1986. Measurements of $\mathrm{SO}_{\mathrm{x}}, \mathrm{NO}_{\mathrm{x}}$ and aerosol species on Bermuda, Atmospheric Environment 20: $1229-1239$. 
Table 1a. Concentration of organic carbon and sulfate (as $\mathrm{SO}_{4}^{2-}$ ) on aerosols with diameter $<2.5 \mu \mathrm{m}$ from remote sites in the continental U.S.a

\begin{tabular}{|c|c|c|c|c|c|}
\hline Location & \multicolumn{2}{|c|}{$\begin{array}{l}\text { Latitude/ } \\
\text { Longitude }\end{array}$} & $\begin{array}{c}\text { Mean } \\
\text { Organic } \\
\text { Carbon } \\
\left(\mu \mathrm{gCm}^{-3}\right)\end{array}$ & $\begin{array}{c}\text { Mean sulfate } \\
\left(\mu \mathrm{gSO} \mathrm{SO}_{4}^{2-} \mathrm{m}^{-3}\right)\end{array}$ & $\begin{array}{c}\text { Ratio } \\
\mu \mathrm{gC} \\
\mu g \mathrm{SO}_{4}^{2-}\end{array}$ \\
\hline Mount Rainier & $46.5 \mathrm{~N}$ & $121.5 \mathrm{~W}$ & 1.6 & 0.83 & 1.9 \\
\hline Crater Lake & $42.5 \mathrm{~N}$ & $122.1 \mathrm{~W}$ & 0.71 & 0.25 & 2.8 \\
\hline Redwood & $37.3 \mathrm{~N}$ & $122.1 W$ & 0.99 & 0.60 & 1.7 \\
\hline Lassen & $40.3 N$ & $121.2 W$ & 0.85 & 0.36 & 2.4 \\
\hline Point Reyes & $38.0 \mathrm{~N}$ & $123.0 \mathrm{~W}$ & 0.64 & 0.95 & 0.67 \\
\hline Yosemite & $37.5 \mathrm{~N}$ & $119.3 \mathrm{~W}$ & 1.4 & 0.55 & 2.6 \\
\hline Pinnacles & $36.3 N$ & $121.2 \mathrm{~W}$ & 1.1 & 1.0 & 1.1 \\
\hline San Gorgonio & $34.1 \mathrm{~N}$ & $116.5 \mathrm{~W}$ & 1.8 & 0.8 & 2.3 \\
\hline Glacier & $48.4 \mathrm{~N}$ & $113.4 \mathrm{~W}$ & 1.5 & 0.60 & 2.5 \\
\hline Jarbidge & $42.2 \mathrm{~N}$ & $115.4 \mathrm{~W}$ & 0.64 & 0.33 & 1.9 \\
\hline Canyonlands & $38.1 \mathrm{~N}$ & $110.0 \mathrm{~W}$ & 0.71 & 0.87 & 0.82 \\
\hline Bryce Canyon & $37.3 N$ & $112.1 \mathrm{~W}$ & 0.64 & 0.68 & 0.94 \\
\hline Grand Canyon & $36.2 \mathrm{~N}$ & $112.6 \mathrm{~W}$ & 0.57 & 0.69 & 0.83 \\
\hline Petrified Forest & $34.6 \mathrm{~N}$ & $109.5 \mathrm{~W}$ & 0.85 & 0.80 & 1.1 \\
\hline Tonto & $33.3 \mathrm{~N}$ & 111. OW & 0.92 & 1.1 & 0.84 \\
\hline Saguaro & $32.1 \mathrm{~N}$ & $110.4 \mathrm{~W}$ & 0.92 & & \\
\hline Chiricahua & $32.0 \mathrm{~N}$ & $109.2 \mathrm{~W}$ & 0.85 & 1.2 & 0.71 \\
\hline Yellowstone & $44.6 \mathrm{~N}$ & $110.4 W$ & 1.6 & 0.44 & 3.6 \\
\hline Bridger & $41.1 \mathrm{~N}$ & $107.0 \mathrm{~W}$ & 0.71 & 0.47 & 1.5 \\
\hline Rocky Mountain & $40.2 \mathrm{~N}$ & $105.4 \mathrm{~W}$ & 0.78 & 0.64 & 1.2 \\
\hline Weminuche & $37.1 \mathrm{~N}$ & $108.3 \mathrm{~W}$ & 0.57 & 0.57 & 1.0 \\
\hline Mesa Verde & $37.1 \mathrm{~N}$ & $108.3 W$ & 0.64 & 0.64 & 1.0 \\
\hline Great Sand Dunes & $37.4 \mathrm{~N}$ & $105.4 \mathrm{~W}$ & 0.64 & 0.64 & 1.0 \\
\hline Bandelier & $35.5 \mathrm{~N}$ & $106.2 \mathrm{~W}$ & 0.85 & 0.73 & 1.2 \\
\hline Guadalupe Mountains & $31.5 \mathrm{~N}$ & $104.6 \mathrm{~W}$ & 0.85 & 1.3 & 0.65 \\
\hline Big Bend & $29.1 \mathrm{~N}$ & $103.1 \mathrm{~W}$ & 0.92 & 1.7 & 0.54 \\
\hline Badlands & $43.5 \mathrm{~N}$ & $102.1 W$ & 0.85 & 0.95 & 0.90 \\
\hline Voyageurs & $48.3 \mathrm{~N}$ & $93.0 W$ & 1.1 & 1.2 & 0.92 \\
\hline Acadia & $44 / 2 \mathrm{~N}$ & $68.2 W$ & 0.92 & 2.3 & 0.4 \\
\hline Shenandoah & $38.5 \mathrm{~N}$ & $78.1 W$ & 2.5 & 4.3 & 0.58 \\
\hline Great Smoky Mountains & $35.4 N$ & $83.3 \mathrm{~W}$ & 2.6 & 3.6 & 0.72 \\
\hline
\end{tabular}

acahill et al. (1990) report annual average concentrations measured over the time period from March 1988 to February 1989. The concentrations reported here were derived from the measured hydrogen concentration of the filter samples, correcting for the hydrogen content of sulfates. The authors claim that this method gives results that are comparable to those from thermal volatilization. Estimates for carbon concentration were converted from the organic carbon mass concentration reported in cahill et al. (1990) to $\mu \mathrm{gcm}^{-3}$ using the recommended conversion factor from that report (718 of organic matter is assumed to be $C$ ). (See also Malm et al., 1994). 
Table 1b. Concentration of carbon on aerosols from remote marine areas.

\begin{tabular}{|c|c|c|c|c|}
\hline Location & $\begin{array}{c}\text { Mean Organic } \\
\text { Carbon }\left(\mu \mathrm{gcm}^{-3}\right)\end{array}$ & $\begin{array}{c}\text { Mean Sulfate } \\
\left(\mu \mathrm{gSO} 4_{4}^{2-} \mathrm{m}^{-3}\right)\end{array}$ & $\begin{array}{c}\text { Ratio } \\
\left(\mu \mathrm{gC} / \mathrm{mgSO}_{4}^{2-}\right)\end{array}$ & $\begin{array}{l}\text { Refer } \\
\text {-ence }\end{array}$ \\
\hline \multicolumn{5}{|l|}{ Northem Hemisphere } \\
\hline Enewetak atoll & $0.82+/-0.17$ & & & a \\
\hline Northern Atlantic & $0.76+1-0.42$ & & & b \\
\hline West coast of Ireland & $0.57+/-0.29$ & & & $\mathrm{c}$ \\
\hline California & $0.49+1-0.26$ & & & d \\
\hline Sargasso Sea & $0.44+/-0.04$ & & & a \\
\hline Atlantic & $0.40+/-0.39$ & & & e \\
\hline Hawaii & $0.39+/-0.03$ & & & $\mathrm{f}$ \\
\hline Tropical Pacific & $0.38+/-0.19$ & & & $g$ \\
\hline Bermuda & $0.37+1-0.23$ & & & $\mathrm{f}$ \\
\hline Bermuda & $0.29+1-0.09$ & & & $\mathrm{~h}$ \\
\hline Bermuda & $0.67+/-0.25$ & $1.95+/-0.11$ & 0.34 & $i$ \\
\hline Eastern Atlantic & $0.35+/-0.15$ & & & j \\
\hline Equatorial Pacific & $0.21+/-0.11$ & & & $\mathrm{k}$ \\
\hline Puerto Rico & $0.66+/-0.14$ & $1.06+1-0.06$ & 0.62 & 1 \\
\hline \multicolumn{5}{|l|}{ Southem Hemisphere } \\
\hline Tasmania & 0.53 & & & $\mathrm{~m}$ \\
\hline Tasmania & $0.23+/-0.07$ & & & $\mathrm{n}$ \\
\hline Tropical Atlantic & $0.23+1-0.08$ & & & e \\
\hline Eastern Tropical Pacific & $0.22+/-0.14$ & & & $\mathrm{~g}$ \\
\hline Samoa & $0.22+1-0.09$ & & & $\mathrm{f}$ \\
\hline Samoa & $0.11+/-0.03$ & & & $\bar{j}$ \\
\hline Peru & $0.16+1-0.07$ & & & $\vec{j}$ \\
\hline Equatorial Pacific & $0.15+/-0.05$ & & & $\mathrm{k}$ \\
\hline Amsterdam Island & 0.15 & & & j \\
\hline New Zealand & $0.13+/-0.02$ & & & j \\
\hline
\end{tabular}

a Chesselet et al. (1981), b Ketseridis et al. (1976), cEichmann et al. (1979), $\mathrm{d}_{\mathrm{Hidy}}$ et al. (1974), e endreae (1983), f foffman and Duce (1977), g $_{\text {Barger }}$ and Garrett (1976), ${ }^{h}$ Hoffman and Duce (1974), ${ }^{i}$ Wolff et al. (1986), jCachier et

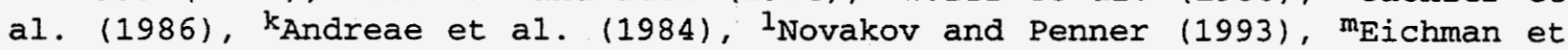
al. $(1980), \mathrm{n}_{\text {Andreae }}(1982)$. 


\section{Joyce E. Penner}

Table 1c. Measured BC concentrations in remote locations ( $\left.\mu \mathrm{g} \mathrm{m}^{-3}\right)$.

\begin{tabular}{lccc}
\hline Location & $\begin{array}{c}\text { Measured } \\
\text { Concentration } \\
\text { (Northern } \\
\text { Hemisphere } \\
\text { winter) }\end{array}$ & $\begin{array}{c}\text { Measured } \\
\text { Concentration } \\
\text { (Northern } \\
\text { Hemisphere } \\
\text { summer) }\end{array}$ & Reference \\
\hline Bermuda & 0.03 & 0.04 & $\mathrm{a}$ \\
Western Atlantic boundary layer & 0.19 & $\mathrm{~b}$ & $\mathrm{c}$ \\
Mid-Atlantic Ocean & 0.002 & 0.02 & $\mathrm{~d}$ \\
Central Pacific & 0.004 & $\mathrm{e}$ \\
Arctic-Ny Alesund & 0.07 & 0.003 & $\mathrm{~d}$ \\
Arctic-Barrow & 0.29 & & $\mathrm{~d}$ \\
& 0.21 & $\mathrm{f}$ \\
South Pole & 0.05 & 0.08 & $\mathrm{f}$ \\
\end{tabular}

aWolff et al. (1986), bWhelpdale et al. (1987), ${ }^{C_{H a n s e n}}$ et al. (1990), dClarke

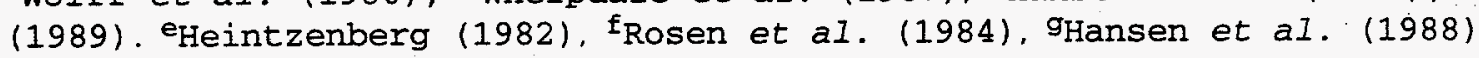


Table 2. Sources of fine particle organic matter and black carbona

Anthropogenic

Biomass burning (savannas, forests, and

agricultural wastes)

Fossil and wood fuel burning, industrial

processes, and fugitive sources

Secondary organics from anthropogenic emissions of NMHCs

Sources of black carbon

Total of anthropogenic sources of

Natural

Forest fires

Black carbon from natural fires

Secondary organics from the

oxidation of terpenes to

condensable vapors

small

Marine sources of organic matter

Emissions of plants and sub-micron $(0-90)$

Total of natural sources

a Total organic matter source strength is estimated as 1.4 times the source strength estimated from the budget for $C$, however, this conversion factor may range from 1.2 to 1.5 times $C$. 


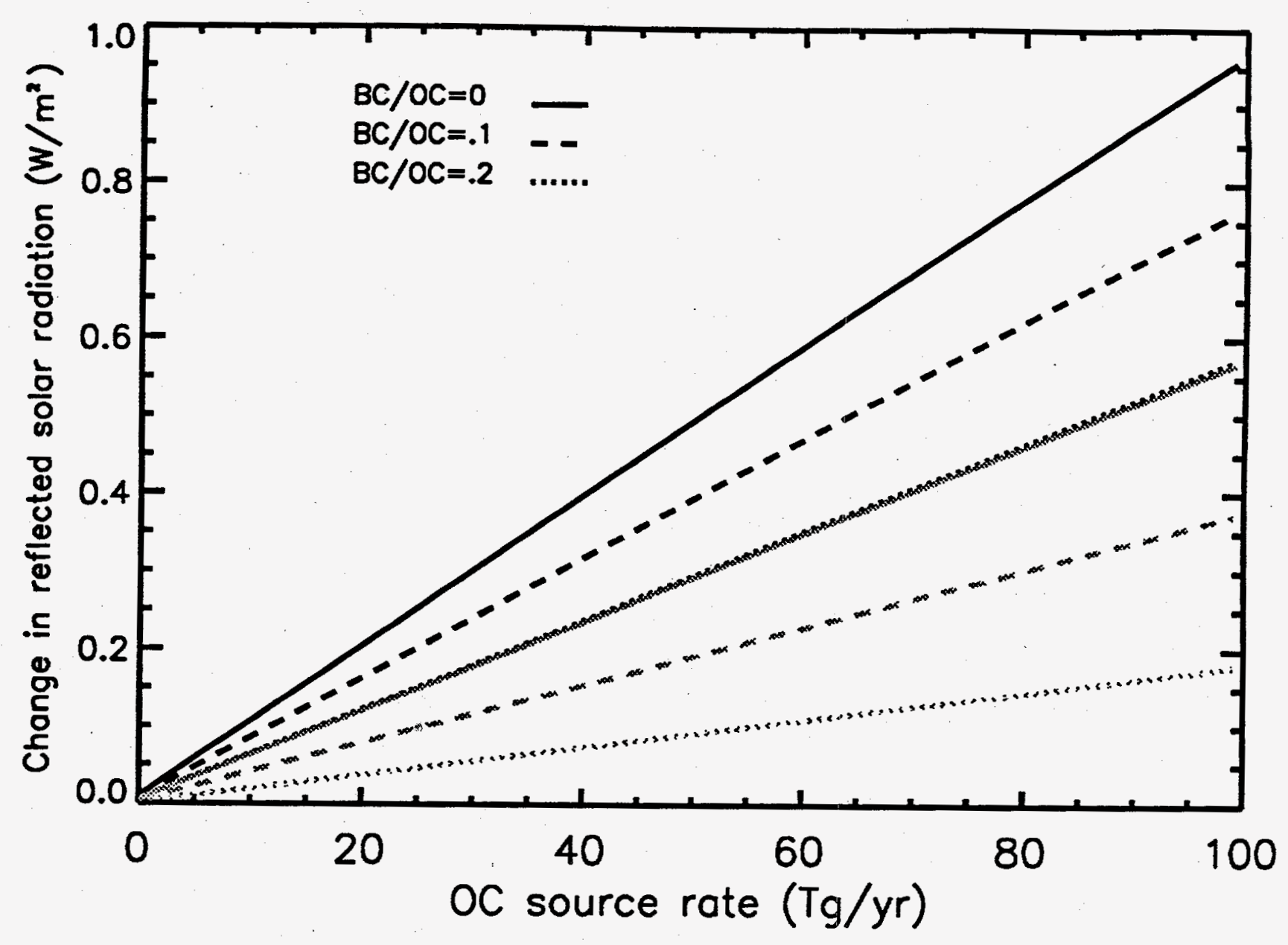

Figure 1. Estimated change in reflected solar radiation $\left(\mathrm{Wm}^{-2}\right)$ from the simple box model described in the text as a function of

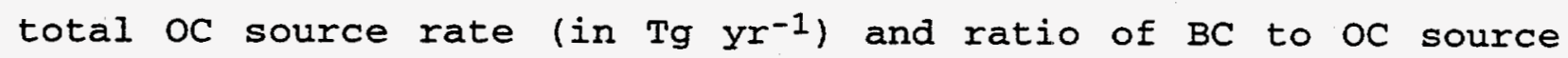
rates. The change is estimated for two cases: $k_{s}(O C)=5 \mathrm{~m}^{2} \mathrm{~g}^{-1}$ and $\mathrm{k}_{\mathrm{s}}(\mathrm{OC})=8.5 \mathrm{~m}^{2} \mathrm{~g}^{-1}$. The bold lines indicate the calculated change for $\mathrm{k}_{\mathrm{s}}(O C)=8.5 \mathrm{~m}^{2} \mathrm{~g}^{-1}$ while the lighter lines show the change for $k_{S}(O C)=5 \mathrm{~m}^{2} \mathrm{~g}^{-1}$. The calculated forcing for $\mathrm{BC} / \mathrm{OC}=0.2$ for $\mathrm{k}_{\mathrm{S}}(\mathrm{OC})$ $=8.5 \mathrm{~m}^{2} \mathrm{~g}^{-1}$ overlaps with that for $\mathrm{BC} / O \mathrm{OC}=0$ and $\mathrm{k}_{\mathrm{S}}(\mathrm{OC})=5 \mathrm{~m}^{2} \mathrm{~g}^{-1}$. 